\title{
Nematoda Puru Akar pada Seledri (Apium graveolens L.) dan Pengendaliannya Menggunakan Bakteri Endofit Secara In Vitro
}

\author{
Rootknot Nematodes in Celery (Apium graveolens L.) and Its in Vitro Control Using Endophytic Bacteria
}

\author{
Fitrianingrum Kurniawati $^{1 *}$, Neng Tipa Nursipa ${ }^{1}$, Abdul Munif $^{1}$ \\ ${ }^{1}$ Departemen Proteksi Tanaman, Fakultas Pertanian, Institut Pertanian Bogor \\ J1. Kamper, Kampus IPB Dramaga, Bogor, 16680 \\ *Email korespondensi: fitrianingrum@apps.ipb.ac.id
}

Diterima: 07 Januari 2020 / Disetujui: 18 Maret 2020.

\begin{abstract}
Root knot nematodes can cause disease on celery. Endophytic bacteria as biocontrol agents is an alternative for controlling nematodes. This research aimed to identify plant-parasitic nematodes that associated with celery in Cikole Village, Cihideung, and Ciputri and control these nematodes using endophytic bacteria. Nematodes were extracted from soil and root samples by flotation-centrifugation and mist chamber techniques. Root knot nematodes were identified based on their morphological characters and were characterized by the female perineal pattern. Endophytic bacteria were isolated from 'kenikir' on TSA 20\%. Bacteria obtained were subsequent hypersensitive test, hemolysis test and in vitro test. Four species of root knot nematodes, which were $M$. incognita, $M$. arenaria, $M$. javanica, and $M$. hapla were identified. Eleven bacteria isolates showed negative reaction on hipersensitive test and hemolysis test. Isolates with code EB45, EB48, EB28, EB13, EB49 caused nematodes mortality with the highest percentage of $53.74 \%, 51.41 \%, 49.45 \%, 47.71 \%$, and $47.69 \%$ at 12 hours after in vitro treatment.
\end{abstract}

Keywords: celery, endophytic bacteria, Meloidogyne, root knot nematodes

\section{ABSTRAK}

Nematoda puru akar (Meloidogyne spp.) merupakan salah satu patogen penyebab penyakit pada seledri. Pengendalian nematoda puru akar menggunakan bakteri endofit merupakan salah satu alternatif pengendalian yang dapat dipertimbangkan. Tujuan dari penelitian ini mengidentifikasi nematoda puru akar yang berasosiasi dengan tanaman seledri di Desa Cikole, Cihideung, dan Ciputri serta pengendaliannya menggunakan bakteri endofit. Ekstraksi nematoda menggunakan metode flotasi-sentrifugasi dan pengabutan. Identifikasi nematoda berdasarkan karakteristik morfologi, dan karakter pola perineal nematoda betina. Bakteri endofit diisolasi dari tanaman kenikir. Bakteri endofit yang didapatkan selanjutnya di uji hipersensitif, uji aktivitas hemolisis dan uji in vitro. Empat spesies nematoda puru akar, yaitu M. incognita, M. arenaria, M. javanica dan M. hapla teridentifikasi berdasarkan karakter pola perineal. Sebanyak 11 isolat menunjukkan reaksi negatif uji hipersensitif dan uji aktivitas hemolisis. Isolat dengan kode EB45, EB48, EB28, EB13, EB49 merupakan isolat dengan jumlah mortalitas nematoda terbanyak dengan persentase berturut-turut 53,74\%, 51,41\%, 49,45\%, 47,71\%, dan 47,69\% pada 12 jam setelah perlakuan pada uji in vitro.

Kata kunci: bakteri endofit, Meloidogyne, nematoda puru akar, seledri

\section{PENDAHULUAN}

Tanaman seledri (Apium graveolens L.) merupakan komoditas sayuran bernilai ekonomi yang sering digunakan sebagai penyedap makanan, bumbu masakan dan penghias hidangan (Kasahara dan Hemmi 1995). Salah satu kendala dalam budi daya tanaman seledri ialah gangguan nematoda parasit akar yang dapat menyebabkan penyakit yang serius dan menimbulkan kehilangan hasil mencapai $70 \%$ di Michigan Amerika Serikat (Melakeberhan dan Wang 2012).

Beberapa jenis nematoda dilaporkan dapat menyebabkan penyakit pada tanaman seledri. Penelitian
Rosya dan Winarto (2013) melaporkan bahwa di Sumatera Barat nematoda yang menyerang tanaman seledri yaitu Helicotylenchus, Trichodorus, Longidorus, Xiphinema dan nematoda puru akar (NPA) Meloidogyne spp.. Luc et al. (2001) menyatakan bahwa tanaman seledri merupakan inang dari M. incognita, M. javanica, dan M. thamesi. Spesies Meloidogyne yang telah dilaporkan berasosiasi dengan seledri di Indonesia adalah $M$. incognita, $M$. arenaria, dan $M$. javanica (Kurniawati et al. 2017).

Meloidogyne spp. merupakan nematoda yang berkembang sangat cepat dan mempunyai daya tekan tinggi terhadap pertumbuhan tanaman dengan gejala khas terlihat 
pada akar, yaitu berupa bintil-bintil yang disebut dengan puru akar (Whitehead 1998). Selain terbentuknya puru akar, akar lebih sedikit, daun mengalami klorosis, layu, banyak yang gugur, dan tanaman kerdil, dan serangan yang berat menyebabkan tanaman mati (Prasasti 2012). Pengendalian nematoda parasit tanaman yang biasa dilakukan yaitu dengan menggunakan nematisida, agens antagonis, dan pergiliran tanaman (Luc et al. 2001). Penggunaan pestisida sintetik dinilai dapat mencemari lingkungan dan menganggu keseimbangan ekosistem apabila penggunaannya tidak terkontrol. Alternatif pengendalian hama dan penyakit tanaman yang ramah lingkungan untuk mendukung kehidupan yang lebih sehat perlu terus dikembangkan. Hal ini sejalan dengan salah satu konsep pengendalian hama terpadu (PHT), yaitu pengendalian hayati dengan memanfaatkan komponen biologi. Konsep ini merupakan salah satu pilihan teknologi pengendalian yang perlu dikembangkan karena rendahnya dampak negatif terhadap lingkungan, murah dan berkelanjutan (sustainable) (Barker dan Koening 1998). Salah satu alternatif pengendalian yang dapat digunakan yaitu penggunaan bakteri endofit.

Bakteri endofit merupakan bakteri saprofit yang hidup dan berasosiasi dengan jaringan tanaman yang sehat tanpa menimbulkan gejala penyakit. Keberadaan bakteribakteri endofit di dalam jaringan tanaman berperan dalam perbaikan pertumbuhan tanaman (plant growth promotion) karena kemampuannya dalam mensintesis dan memobilisasi fosfat, hormon pertumbuhan dan enzim serta berperan dalam ketahanan tanaman sebagai agens hayati. Bakteri endofit diduga mampu memproduksi antibiotik dan senyawa antimikroba lainnya yang sangat berperan dalam menginduksi ketahanan tanaman terhadap serangan penyakit dan hama. Bakteri endofit dapat ditemukan di berbagai jenis tanaman seperti tanaman hortikultura, perkebunan, pangan, dan kehutanan (Munif et al., 2012). Munif dan Harni (2011) berhasil mengisolasi bakteri endofit dari tanaman lada dan beberapa diantaranya terbukti efektif dalam menekan jumlah puru pada akar dan populasi juvenil nematoda $M$. incognita di dalam tanah hingga mencapai $90 \%$.

Penelitian ini bertujuan untuk mengidentifikasi NPA yang berasosiasi dengan tanaman seledri di Desa Cikole Kecamatan Lembang, Desa Cihideung Kecamatan Parongpong Bandung Barat dan Desa Ciputri Kecamatan Pacet Cianjur dan mengetahui potensi bakteri endofit asal tanaman kenikir dalam mengendalikan NPA.

\section{BAHAN DAN METODE}

\section{Pengambilan Sampel dan Pengamatan Gejala}

Pengambilan sampel dilakukan dengan metode purposif di lahan seledri milik petani di Desa Cikole, Desa Cihideung dan Desa Ciputri. Sampel yang diambil berupa tanah dan akar tanaman seledri. Pengambilan sampel tanah dilakukan dengan menggunakan bor tanah (diameter $5 \mathrm{~cm}$ ) pada kedalaman $15 \mathrm{~cm}$ dengan jarak $10 \mathrm{~cm}$ dari batang tanaman. Sampel tanah kemudian dimasukkan ke dalam kantong plastik dan amplop berwarna coklat yang telah diberi label dan dibawa ke laboratorium. Pengambilan sampel akar dilakukan dengan mencabut akar tanaman seledri sampai bagian pangkal. Sampel akar kemudian dimasukan dalam kantong plastik dan amplop berwarna coklat yang telah diberi label dan dibawa ke laboratorium. Selain itu, dilakukan pendataan untuk mendapatkan informasi awal mengenai tipe gejala tanaman yang disebabkan oleh nematoda Meloidogyne spp.

\section{Ekstraksi Nematoda dari Sampel Tanah}

Sampel tanah dipisahkan dari gumpalan. Tanah yang halus diambil sebanyak $100 \mathrm{ml}$ dan dicampurkan dengan $800 \mathrm{ml}$ air dalam ember A, lalu diendapkan selama 1 menit. Air dari ember A disarig ke dalam ember B dengan menggunakan saringan kasar. Air dalam ember B disaring diatas saringan bertumpuk dengan posisi miring $30^{\circ}$, yaitu berturut-turut saringan 20 mesh, 50 mesh dan 400 mesh. Substrat tanah dan nematoda yang tertinggal di saringan 400 mesh dituang ke dalam tabung sentrifuse. Substrat di sentrifugasi selama \pm 5 menit dengan kecepatan $1500 \mathrm{rpm}$, kemudian supernatan dibuang. Endapan ditambahkan dengan larutan gula $40 \%$ dan diaduk sampai merata. Selanjutnya disentrifugasi selama \pm 1 menit dengan kecepatan $1700 \mathrm{rpm}$. Supernatan yang terbentuk disaring dengan saringan 500 mesh dan dibilas dengan air yang mengalir sehingga diperoleh suspensi nematoda, lalu dimasukkan dalam botol koleksi untuk diamati dan diidentifikasi (Caveness \& Jensen 1955).

\section{Ekstraksi Nematoda dari Sampel Akar}

Nematoda diekstraksi dari sampel akar dengan menggunakan metode pengabutan (mist chamber). Akar seledri terlebih dahulu dibersihkan kemudian di potongpotong sepanjang $\pm 1 \mathrm{~cm}$ dan ditimbang sebanyak $5 \mathrm{~g}$. Akar yang telah di potong-potong disimpan diatas saringan kasar, lalu diletakkan diatas corong yang dibawahnya terdapat gelas plastik untuk penampung nematoda, kemudian disimpan di ruang pengabutan dan dibiarkan selama 48 jam. Setelah itu gelas plastik yang berisi nematoda disaring dengan menggunakan saringan 400 mesh dengan posisi saringan agak miring. Nematoda yang bertahan dalam saringan dipindahkan dan disimpan dalam botol koleksi lalu dimasukkan dalam kulkas untuk pengamatan selanjutnya (Hutagalung 1988).

\section{Pembuatan Preparat Nematoda Semipermanen}

Preparat semi permanen dibuat berdasarkan metode Goodey (1937) yang telah dimodifikasi. Lingkaran parafin dibuat diatas gelas objek dengan menggunakan bor gabus (cork borer) dengan ketebalan yang sama, kemudian diteteskan laktofenol pada tengah-tengah lingkaran parafin. Sebanyak 3-5 ekor nematoda diletakkan pada larutan laktofenol dengan posisi yang sama sejajar, selanjutnya ditutup dengan cover glass. Preparat kemudian dipanasi sampai cincin parafin meleleh kembali dan cover glass merekat bersama parafin. Pinggir cover glass direkatkan dengan kuteks transparan. 


\section{Identifikasi Morfologi}

Pengamatan secara morfologi dilakukan dengan melihat ciri dari tiap fase perkembangan nematoda tersebut. Pengamatan dilakukan dengan menggunakan kamera. Identifikasi dilakukan dengan mengacu pada buku identifikasi nematoda yaitu Plant Parasitic Nematodes : a Pictorial Key to Genera (May \& Lyon 1996) dan Nematology Laboratory Investigations Morphology And Taxonomy (Eisenback 2003)

\section{Penghitungan Nematoda}

Penghitungan jumlah nematoda dari sampel tanah dan akar dilakukan di bawah mikroskop stereo dengan perbesaran 40x. Jumlah sampel tiap penghitungan sebanyak $1 \mathrm{ml}$ dan dilakukan sebanyak 5x ulangan.

\section{Isolasi Bakteri Endofit}

Isolasi bakteri endofit dari akar dan batang tanaman kenikir dilakukan dengan menggunakan metode yang dilakukan oleh Hallmann et al. (1997) dengan modifikasi. Masing-masing sampel akar dan batang dicuci dengan air mengalir sampai bersih, kemudian dikeringkan dengan kertas tissu dan ditimbang sebanyak 2 g, selanjutnya akar disterilisasi permukaan dengan menggunakan $\mathrm{NaOCl} 3 \%$ yang telah diberi $0.01 \%$ Tween 20 selama 3 menit kemudian akar dibilas dengan air steril sebanyak 4 kali. Untuk mengetahui apakah sterilisasi permukaan berhasil atau tidak, diuji dengan meletakkan akar dan batang yang sudah disterilkan ke dalam cawan petri yang sudah diisi media Tryptic Soy Agar (TSA) 20\%, dan diinkubasi selama 48 jam. Akar maupun batang yang masih ditemukan mikroorganisme yang tumbuh pada permukaan akar, berarti sterilisasi gagal dan bakteri yang diperoleh tidak dapat digunakan. Perlakuan ini bertujuan agar bakteri yang diperoleh betul-betul berasal dari jaringan akar dan bukan dari permukaan akar (kontaminan). Akar yang sudah steril dihancurkan dengan mortar steril sampai halus. Ekstrak akar disuspensikan dengan $9 \mathrm{ml}$ air steril dalam tabung reaksi. Suspensi dikocok dengan menggunakan vorteks, selanjutnya dipindahkan sebanyak $1 \mathrm{ml}$ suspensi ke dalam $9 \mathrm{ml}$ air steril pada tabung reaksi. Dengan demikian diperoleh tingkat pengenceran $10^{-2}$ dan selanjutnya dilakukan pengenceran dengan cara yang sama dan diperoleh suspensi $10^{-3}$. Selanjutnya dari pengenceran $10^{-3}$ diambil $0.1 \mathrm{ml}$ suspensi untuk ditumbukan pada media TSA $20 \%$, diinkubasi selama 48 jam pada suhu kamar. Koloni bakteri yang tumbuh dimurnikan pada media TSA $100 \%$. Bakteri yang sudah murni disimpan di dalam ependorf yang telah berisi media air steril kemudian disimpan pada suhu $-80{ }^{\circ} \mathrm{C}$.

\section{Uji Hipersensitif}

Uji hipersensitif dilakukan untuk mengetahui potensi patogenesitas bakteri endofit. Tanaman yang digunakan dalam uji ini adalah tanaman tembakau sehat berumur 3-4 bulan. Isolat bakteri endofit yang akan diuji dibiakkan pada media TSA $100 \%$ dan diinkubasi selama 48 jam. Setelah itu, sebanyak $20 \mathrm{ml}$ akuades steril dituangkan pada biakan dan bakteri dipanen dengan cara meluruhkannya menggunakan jarum inokulasi. Bakteri endofit yang telah diencerkan tersebut kemudian disuntikkan dengan menggunakan jarum suntik pada daun tembakau dan diinkubasi selama 24 jam. Bakteri yang bereaksi positif akan menunjukkan gejala nekrosis pada daun tembakau. Bakteri yang bereaksi negatif tidak menunjukkan gejala kerusakan pada daun tembakau dan digunakan untuk pengujian selanjutnya.

\section{Uji Akivitas Hemolisis}

Isolat bakteri endofit ditumbuhkan pada media agar darah yang diperoleh dari Lab Bakteriologi Tumbuhan Departemen Proteksi Tanaman Institut Pertanian Bogor dan selanjutnya diinkubasi selama 24 jam. Adanya aktivitas hemolisis ditandai dengan adanya zona hemolisis pada plat agar darah.

\section{Uji Bakteri Endofit terhadap Nematoda Parasit secara In Vitro}

Uji ini dilakukan untuk mengetahui aktivitas antibiosis bakteri endofit yang diisolasi terhadap juvenil 2 (j2) nematoda parasit. Uji ini dilakukan dengan cara memasukkan $1 \mathrm{ml}$ suspensi nematoda yang berisi \pm 100 ekor larva nematoda ke dalam $5 \mathrm{ml}$ suspensi bakteri endofit. Suspensi bakteri endofit dibuat dengan cara sebanyak $20 \mathrm{ml}$ akuades steril dituangkan pada biakan isolat bakteri endofit yang berumur 48 jam dan dipanen dengan cara meluruhkannya menggunakan jarum inokulasi. Perlakuan ini dilakukan sebanyak 3 kali ulangan untuk setiap perlakuan. Perhitungan jumlah mortalitas nematoda dilakukan 2, 6, dan 12 jam setelah perlakuan.

\section{Analisis Data}

Rancangan percobaan yang dilakukan pada uji in vitro adalah Rancangan Acak Lengkap (RAL). Data yang diperoleh dianalisis secara statistika dengan menggunakan uji Duncan pada program SAS 9.1.3 dengan selang kepercayaan $95 \%$.

\section{HASIL DAN PEMBAHASAN}

\section{Kondisi Lokasi Pengambilan Sampel dan Gejala yang Ditemukan}

Suhu pada pengambilan sampel di lokasi pengambilan sampel berturut-turut berkisar $19-24{ }^{\circ} \mathrm{C}, 18-22$ ${ }^{\circ} \mathrm{C}, 18-26{ }^{\circ} \mathrm{C}$. Jenis tanah pada ketiga lokasi memiliki tipe yang sama, yaitu tipe andosol. Varietas seledri yang banyak dibudidayakan oleh petani yaitu varietas lokal. 
Gejala sekunder terlihat di atas permukaan tanah, yaitu pertumbuhan tanaman lambat, gejala defisiensi hara seperti kerdil, daun menguning (klorosis), dan layu pada cuaca panas (Dropkin 1991). Gejala sekunder di lahan terdapat daun berwarna kuning atau klorosis (Gambar 2a dan 2b) dan pada saat tanaman dicabut terdapat puru yang banyak dengan rambut akar pada akar seledri tersebut (Gambar 2c).

Terbentuknya puru pada akar disebabkan oleh Meloidogyne spp. yang dapat menghasilkan sekresi protase sehingga mengubah protein di dalam jaringan akar menjadi asam amino. Salah satu asam amino yang dihasilkan yaitu triptofan yang diduga dapat bertindak sebagai perangsang terjadinya hormon IAA. Zat tumbuh tersebut merangsang terjadinya hiperplasia (pertambahan banyak sel yang tidak normal) dan hipertropi (pertambahan besar sel yang tidak normal) (Mulyadi 2009).

\section{Meloidogyne spp. yang Ditemukan pada Sampel Tanah dan Akar}

Rata-rata jumlah populasi nematoda parasit di Desa Cikole yaitu 444 ekor Meloidogyne spp., di Desa Cihideung lahan monokultur yaitu 330 ekor Meloidogyne spp, dan pada lahan tumpang sari rata-rata jumlah populasi nematoda parasit yaitu 410 ekor Meloidogyne spp. Rata-rata jumlah populasi nematoda parasit di Desa Ciputri lahan monokultur yaitu 200 ekor Meloidogyne spp., pada lahan tumpangsari dengan bawang daun rata-rata jumlah populasi nematoda parasit yaitu 410 ekor Meloidogyne spp, serta rata-rata jumlah populasi nematoda Meloidogyne spp. dari sampel akar Desa Cihideung lahan monokultur yaitu 508 ekor, tumpang sari 2068 ekor Meloidogyne spp. Rata-rata jumlah populasi nematoda parasit di Desa Ciputri lahan monokultur yaitu 400 ekor Meloidogyne spp, dan tumpang sari 1290 ekor.

Menurut Jayasinghe (2002), juvenil stadia 2 (J2) Meloidogyne merupakan stadia paling infektif untuk melakukan penetrasi ke dalam perakaran. Setelah J2 masuk kedalam akar, J2 bergerak di antara sel-sel sampai di tempat dekat silinder pusat. Di tempat tersebut nematoda menetap dan menyebabkan perubahan sel-sel yang menjadi makanannya (Dropkin 1991). Panjang tubuh J2 yang ditemukan yaitu $100,911 \mu \mathrm{m}$, stilet tipe stomatostilet dengan panjang 9,87 $\mu \mathrm{m}$, basal knob offset, tubuh Meloidogyne bervariasi tergantung dari spesies. Fase istirahat Meloidogyne juvenil 2 memperlihatkan bentuk tubuh yang relatif lurus, tipe bibir tidak set-off atau tidak memiliki lengkungan bibir, anulasi halus, dan ujung ekor terlihat bergerigi (Gambar 2).

Karakter yang paling sering digunakan untuk identifikasi morfologi spesies Meloidogyne spp. betina adalah menggunakan pola perineal. Pola perineal tersebut terletak di bagian posterior nematoda betina dewasa. Hasil identifikasi pola perineal menunjukkan adanya empat spesies Meloidogyne spp. di kelima lokasi pengambilan sampel. Keempat spesies tersebut adalah $M$. incognita, $M$. javanica, $M$. arenaria, dan $M$. hapla. Masing-masing spesies nematoda betina tersebut dapat dikenali berdasarkan ciri khas dari pola perineal yang dimiliki. Perbedaan pola perineal dari keempat spesies dapat dilihat pada Gambar 3 .

M. incognita mempunyai ciri khas lengkung dorsal yang tinggi dan menyempit, sedangkan bagian paling luar sedikit melebar dan agak mendatar. Pola striasi kasar, bergelombang kadang zig-zag, tidak memiliki garis lateral dan bagian stria terlihat jelas (Gambar 3a dan 3e). $M$. javanica mempunyai ciri khas berupa garis lateral yang terputus dan seperti memisahkan bagian lengkung dorsal dan ventral. Striasi kasar, halus sampai sedikit bergelombang (Gambar 3b dan 3f). M. arenaria mempunyai ciri khusus berupa lengkung dorsal yang rendah dan membulat, tidak terdapat garis pada bidang lateral. Striasi kasar, halus hingga sedikit bergelombang. Bagian lengkung striasi bercabang di dekat garis lateral dengan bagisan striasi lebih mendatar (Gambar 3c dan 3g). M. hapla memiliki ciri khas terdapat tonjolan-tonjolan seperti duri pada zona ujung ekor (Gambar 3d dan 3h).

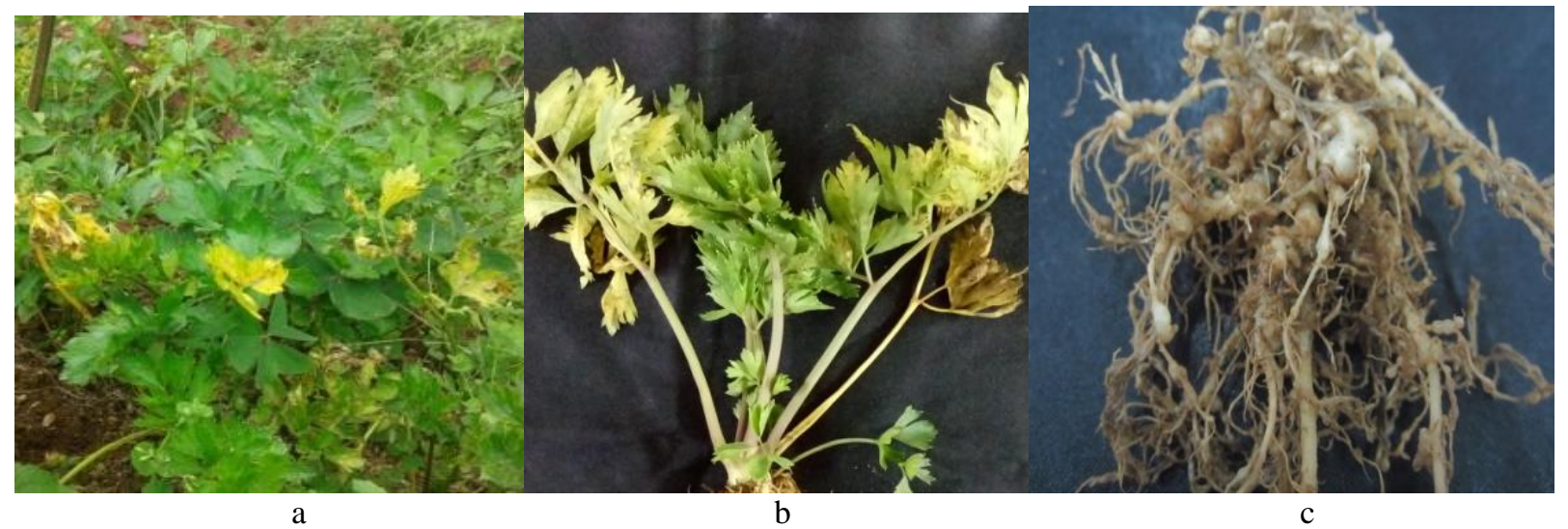

Gambar 1 Gejala tanaman seledri yang terserang nematoda parasit. a) Gejala seledri di lapangan, b) Gejala sekunder, c) Gejala primer 


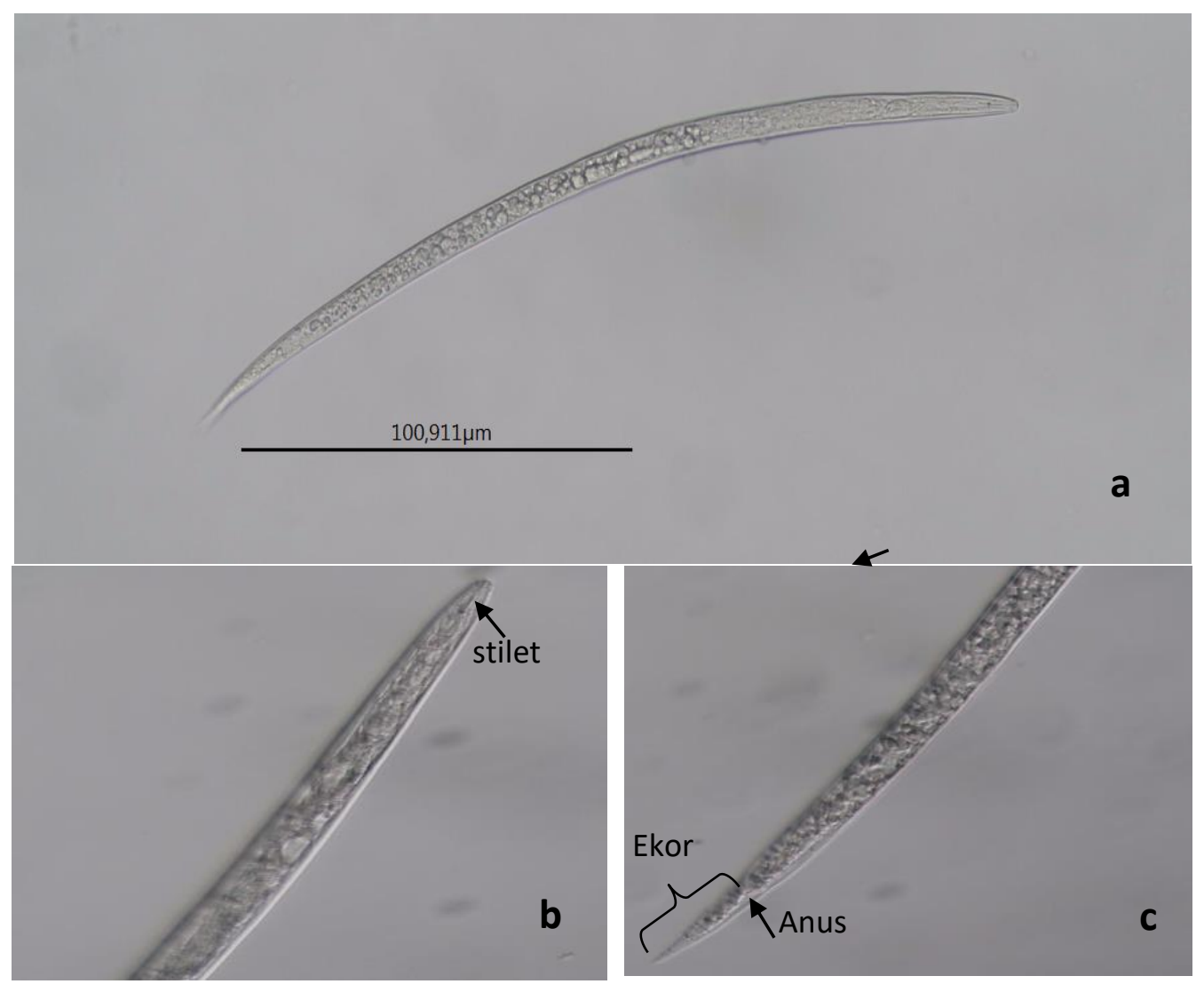

Gambar 2. Morfologi Meloidogyne juvenil. a) Seluruh tubuh (perbesaran 20x10), b) bagian tubuh anterior (Perbesaran 40x10), dan c) bagian tubuh posterior (Perbesaran 40x10).

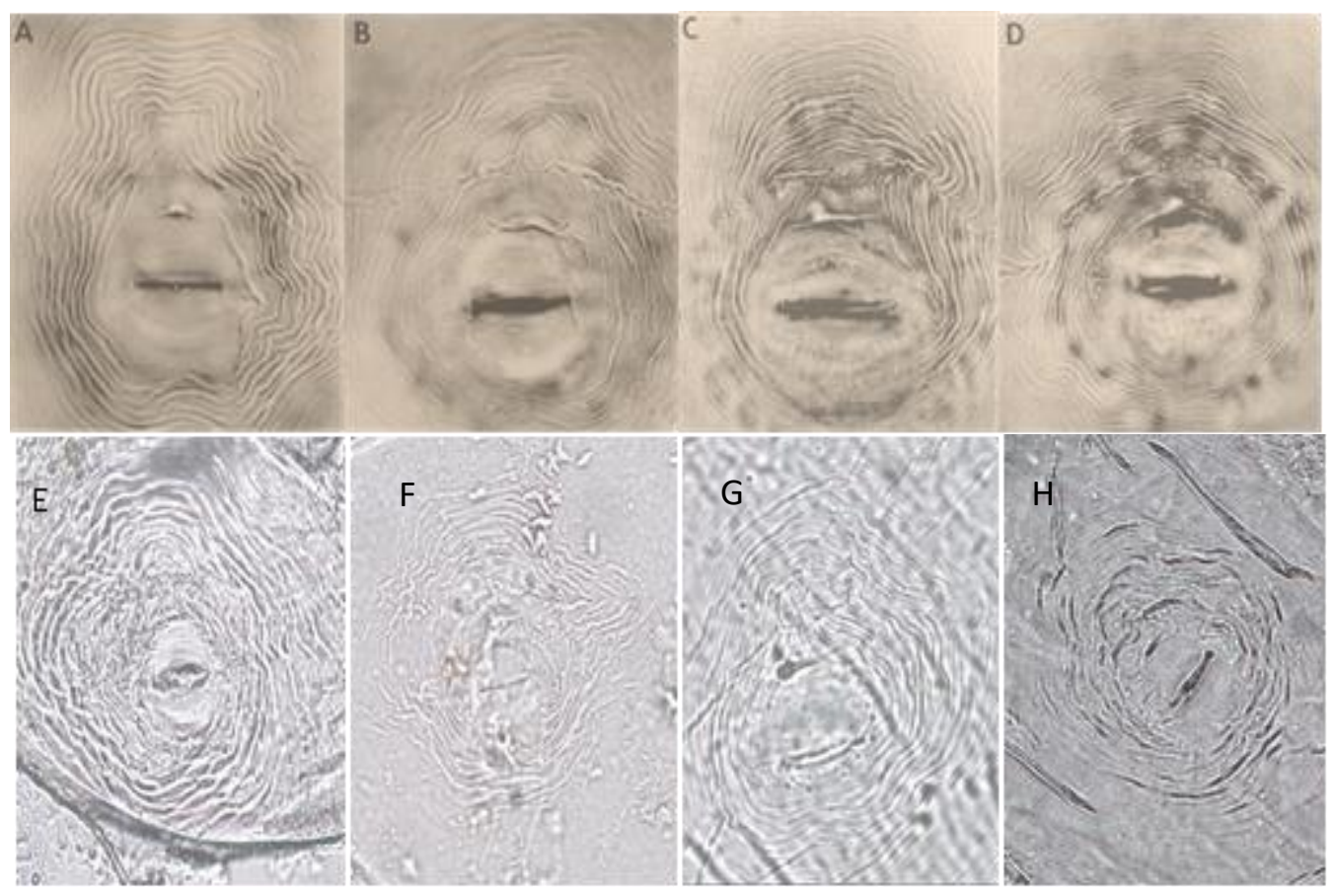

Gambar 3. Pola perineal Meloidogyne betina dewasa. a) M. incognita, b) M.arenaria, c) M. javanica, d) M. hapla (Eisenback et al. 1981). Hasil identifikasi berdasarkan morfologi pola perineal e) M. incognita, f) M. javanica, g) M. arenaria, h) M. hapla 


\section{Isolasi Bakteri Endofit}

Bakteri yang berhasil diisolasi sebanyak 101 isolat yang terdiri dari 51 isolat berasal dari akar, dan 50 isolat dari batang. Isolat tersebut di murnikan pada media TSA 100\% dan disimpan di dalam lemari es pada suhu -40C (Gambar 4).

\section{Uji Reaksi Hipersensitif}

Sebanyak 101 isolat bakteri endofit selanjutnya dilakukan pengujian hipersensitif pada tanaman tembakau. Hasil pengujian menunjukkan 29 isolat tidak menunjukan gejala nekrosis pada daun tembakau (reaksi negatif), sedangkan 72 isolat menunjukkan gejala (reaksi positif) (Tabel 3). Reaksi ini adalah respon tanaman terhadap munculnya patogen di dalam jaringan tanaman yang merupakan usaha untuk menghambat pertumbuhan patogen. Reaksi hipersensitif dipengaruhi oleh gen hrp yang umum terdapat pada bakteri gram negatif patogen tanaman, seperti kelompok Xanthomonas sp. (Zhu et al. 2000). Bakteri yang tidak menunjukkan gejala nekrosis pada daun tembakau (reaksi nematif) digunakan untuk pengujian selanjutnya (Gambar 5).

Lelliott dan Stead (1987) menyebutkan bahwa kebanyakan bakteri patogen tanaman dapat menginduksi respon hipersensitif jika diinjeksikan ke dalam jaringan tanaman inang yang tidak rentan dalam waktu 24-72 jam setelah inokulasi. Menurut Yang He (1996) uji hipersensitif merupakan salah satu metode yang dapat digunakan untuk mendeteksi dengan cepat potensi patogenisitas suatu bakteri terhadap tanaman. Reaksi uji hipersensitif terjadi dalam waktu 24-48 jam dan terlokalisasi. Membran seluler pada daun tanaman tembakau yang mengalami kontak dengan bakteri patogen akan hancur dan nekrosis. Respons tersebut menunjukkan bahwa bakteri yang kontak dengan daun tanaman tembakau berpotensi sebagai patogen tumbuhan (Zhu et al. 2000). Berdasarkan uji yang telah dilakukan, isolat yang negatif hipersensitif berasal dari bagian akar berjumlah 15 isolat. Isolat yang berasal dari bagian batang yang negatif uji hipersensitif berjumlah 14 isolat (Tabel 3).

\section{Uji Aktivitas Hemolisis}

Bakteri yang tidak menunjukkan gejala nekrotik pada uji hipersensitif digunakan untuk uji agar darah untuk melihat keamanannya terhadap kesehatan mamalia. Terdapat 29 isolat bakteri endofit yang diuji dengan metode ini. Berdasarkan hasil uji diketahui terdapat 18 isolat bakteri endofit yang menunjukkan reaksi positif (Gambar 6) dan 11 isolat menunjukkan reaksi negatif. Prinsip pengujian hemolisis adalah melihat perubahan warna media ketika bakteri ditumbuhkan di atas medium padat darah segar (Das et al. 2008). Munculnya perubahan warna dari merah darah menjadi warna gelap (transparan tidak berwarna) telah tampak disekitar koloni bakteri tumbuh. Hal ini menunjukkan aktivitas bakteri mampu melisiskan sel-sel darah merah selama 48 jam waktu inkubasi.

Bakteri yang menghasilkan toksin hemolisin tidak digunakan pada pengujian selanjutnya karena telah diketahui supernatan dari $\alpha$ hemolisin bersifat sangat cytotoxic terhadap granulocytes, monocytes, dan lymphocytes manusia (Lopes et al. 2010). Serratia marcescens diketahui mampu meyebabkan hemolisis pada eritosit manusia (Hertle et al. 1999).

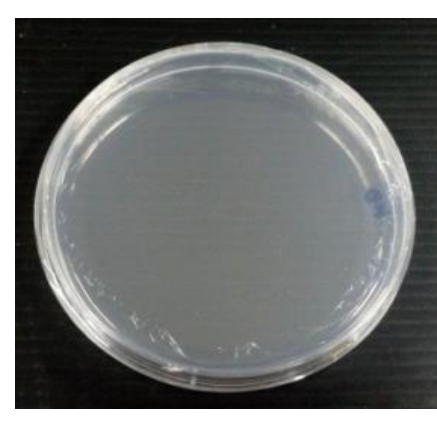

a

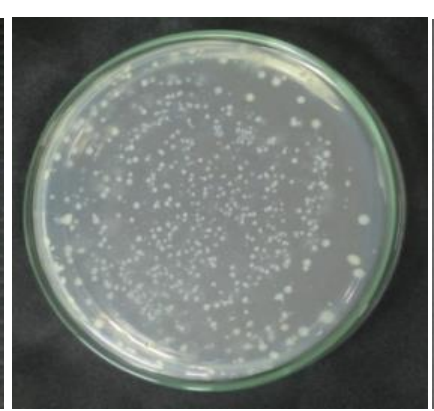

b
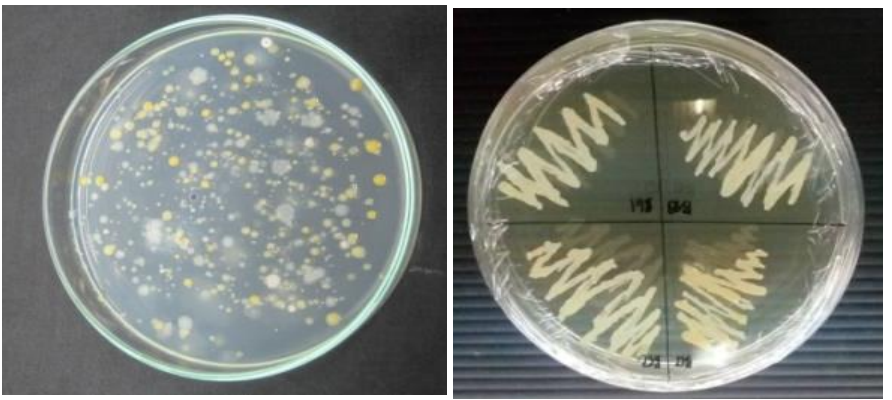

d

Gambar 4. Hasil isolasi dari akar dan batang kenikir pada media TSA. a) kontrol, b) isolat akar, c) isolat batang, d) bakteri yang di remajakan pada media TSA $100 \%$ 


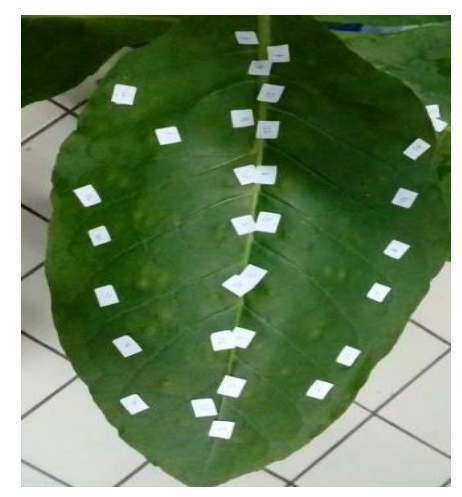

A

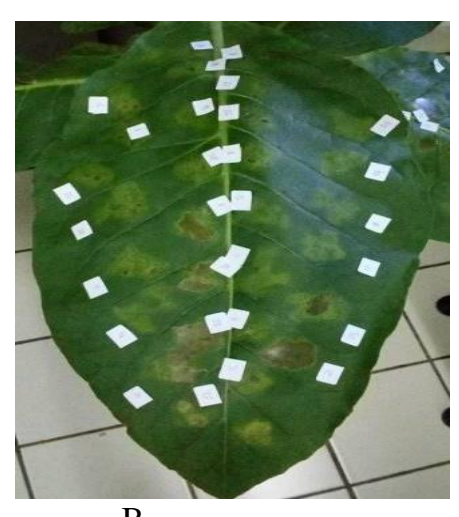

B

Gambar 5 Hasil uji reaksi hipersensitif. A) Isolat bakteri yang tidak menunjukkan gejala nekrosis (reaksi negatif), B) Isolat bakteri endofit yang menunjukkan gejala nekrosis (reaksi positif) pada uji hipersensitif menggunakan daun tembakau

Tabel 3. Isolat bakteri endofit yang diisolasi dari tanaman kenikir dan hasil uji hipersensitif pada tanaman tembakau

\begin{tabular}{|c|c|}
\hline Kode isolat & Uji hipersensitif \\
\hline EA1 & Positif \\
\hline EA2 & Positif \\
\hline EA3 & Positif \\
\hline EA4 & Positif \\
\hline EA5 & Positif \\
\hline EA6 & Positif \\
\hline EA7 & Positif \\
\hline EA8 & Positif \\
\hline EA9 & Positif \\
\hline EA10 & Positif \\
\hline EA11 & Positif \\
\hline EA12 & Positif \\
\hline EA13 & Positif \\
\hline EA14 & Positif \\
\hline EA15 & Positif \\
\hline EA16 & Positif \\
\hline EA17 & Positif \\
\hline EA18 & Positif \\
\hline EA19 & Positif \\
\hline EA20 & Positif \\
\hline EA21 & Positif \\
\hline EA22 & Positif \\
\hline EA23 & Positif \\
\hline EA24 & Positif \\
\hline EA25 & Positif \\
\hline EA26 & Positif \\
\hline EA27 & Positif \\
\hline EA28 & Positif \\
\hline EA29 & Positif \\
\hline EA30 & Positif \\
\hline
\end{tabular}




\begin{tabular}{|c|c|}
\hline EA31 & Negatif \\
\hline EA32 & Negatif \\
\hline EA33 & Positif \\
\hline EA34 & Positif \\
\hline EA35 & Negatif \\
\hline EA36 & Negatif \\
\hline EA37 & Negatif \\
\hline EA38 & Negatif \\
\hline EA39 & Positif \\
\hline EA40 & Negatif \\
\hline EA41 & Positif \\
\hline EA42 & Positif \\
\hline EA43 & Negatif \\
\hline EA44 & Positif \\
\hline EA45 & Positif \\
\hline EA46 & Negatif \\
\hline EA47 & Positif \\
\hline EA48 & Negatif \\
\hline EA49 & Positif \\
\hline EA50 & Positif \\
\hline EA51 & Positif \\
\hline EB1 & Positif \\
\hline EB2 & Positif \\
\hline EB3 & Negatif \\
\hline EB4 & Negatif \\
\hline EB5 & Positif \\
\hline EB6 & Positif \\
\hline EB7 & Negatif \\
\hline EB8 & Negatif \\
\hline EB9 & Positif \\
\hline EB10 & Negatif \\
\hline EB11 & Positif \\
\hline EB12 & Negatif \\
\hline EB13 & Negatif \\
\hline EB14 & Negatif \\
\hline EB15 & Positif \\
\hline EB16 & Positif \\
\hline EB17 & Positif \\
\hline EB18 & Positif \\
\hline EB19 & Positif \\
\hline EB20 & Positif \\
\hline EB21 & Negatif \\
\hline EB22 & Negatif \\
\hline EB23 & Positif \\
\hline EB24 & Positif \\
\hline
\end{tabular}


EB25

EB26

EB27

EB28

EB29

EB30

EB31

EB32

EB33

EB34

EB35

EB36

EB37

EB38

EB39

EB40

EB41

EB42

EB43

EB44

EB45

EB46

EB47

EB48

EB49

EB50
Positif

Positif

Negatif

Negatif

Negatif

Negatif

Positif

Positif

Positif

Positif

Positif

Negatif

Positif

Positif

Negatif

Positif

Positif

Positif

Positif

Positif

Negatif

Positif

Positif

Negatif

Negatif

Positif

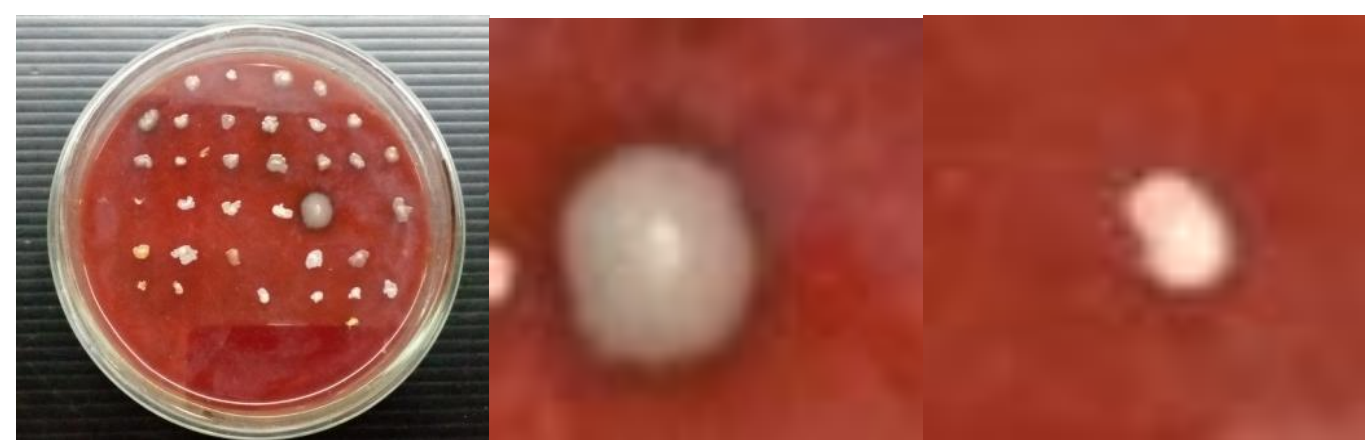

Gambar 6. Hasil uji aktivitas hemolisis. a) isolat bakteri yang diuji agar darah, b) isolat yang menunjukkan hemolisis, c) isolat yang tidak menghasilkan hemolisis 
Tabel 4 Isolat bakteri endofit hasil uji aktivitas hemolisis

\begin{tabular}{cc}
\hline Kode isolat & Uji agar darah \\
\hline EA3 & Positif \\
EA3 & Negatif \\
EA3 & Positif \\
EA3 & Positif \\
EA3 & Positif \\
EA3 & Positif \\
EA4 & Negatif \\
EA4 & Positif \\
EA4 & Positif \\
EA4 & Positif \\
EB3 & Negatif \\
EB4 & Negatif \\
EB7 & Positif \\
EB8 & Positif \\
EB1 & Positif \\
\hline
\end{tabular}

\begin{tabular}{cc}
\hline Kode isolat & Uji agar darah \\
\hline EB12 & Positif \\
EB13 & Negatif \\
EB14 & Positif \\
EB21 & Positif \\
EB22 & Positif \\
EB27 & Positif \\
EB28 & Negatif \\
EB29 & Positif \\
EB30 & Negatif \\
EB36 & Negatif \\
EB39 & Positif \\
EB45 & Negatif \\
EB48 & Negatif \\
EB49 & Negatif
\end{tabular}

Tabel 5 Pengaruh perlakuan bakteri endofit terhadap jumlah mortalitas nematoda parasit secara in vitro

\begin{tabular}{clccc}
\hline \multirow{2}{*}{ No } & Nama isolat & \multicolumn{3}{c}{ Mortalitas } \\
\cline { 3 - 5 } & Kontrol & $2 \mathrm{jam}$ & $6 \mathrm{jam}$ & $12 \mathrm{jam}$ \\
\hline 1 & EA32 & $2.34 \mathrm{~d}$ & $2.34 \mathrm{~g}$ & $2.34 \mathrm{~g}$ \\
2 & EA40 & $13.19 \mathrm{bc}$ & $21.91 \mathrm{de}$ & $33.29 \mathrm{e}$ \\
3 & EB3 & $6.40 \mathrm{bcd}$ & $28.70 \mathrm{~cd}$ & $39.33 \mathrm{cde}$ \\
4 & EB4 & $13.55 \mathrm{ef}$ & $21.24 \mathrm{f}$ \\
5 & EB13 & $14.75 \mathrm{bcc}$ & $32.26 \mathrm{bc}$ & $37.03 \mathrm{de}$ \\
6 & EB28 & $41.30 \mathrm{a}$ & $47.71 \mathrm{abc}$ \\
7 & EB30 & $7.58 \mathrm{bcd}$ & $22.25 \mathrm{de}$ & $49.45 \mathrm{ab}$ \\
8 & EB36 & $10.55 \mathrm{bcd}$ & $12.17 \mathrm{f}$ & $25.06 \mathrm{f}$ \\
9 & EB45 & $25.54 \mathrm{a}$ & $39.46 \mathrm{~cd}$ & $44.17 \mathrm{bcd}$ \\
10 & EB48 & $12.07 \mathrm{bcd}$ & $19.12 \mathrm{ef}$ & $53.74 \mathrm{a}$ \\
11 & EB49 & $17.06 \mathrm{ab}$ & $28.59 \mathrm{~cd}$ & $51.41 \mathrm{ab}$ \\
12 & & & $47.69 \mathrm{abc}$ \\
\hline
\end{tabular}

Uji Bakteri Endofit terhadap Mortalitas Nematoda Parasit secara In Vitro

Uji in vitro dilakukan untuk mengetahui pengaruh langsung bakteri terhadap nematoda parasit. Isolat yang digunakan dalam uji ini merupakan isolat dari hasil uji sebelumnya yaitu EA32, EA40, EB3, EB4, EB13, EB28, EB30, EB36, EB45, EB48, EB49. Tabel 5 menunjukkan bahwa perlakuan dengan isolat bakteri endofit memberikan pengaruh terhadap peningkatan jumlah nematoda parasit yang mengalami kematian dibandingkan dengan kontrol. Kecuali pada perlakuan 2 jam isolat dengan kode EA40, EB3, EB28, EB30, EB36, EB48 tidak berbeda nyata dengan kontrol.

Perlakuan bakteri endofit terhadap nematoda parasit menyebabkan nematoda mengalami kematian pada pengamatan 2 jam setelah perlakuan dan terus meningkat 6 dan 12 jam setelah perlakuan. Hal ini menunjukkan bahwa perlakuan dengan isolat bakteri endofit dengan penambahan waktu memberikan pengaruh terhadap peningkatan mortalitas nematoda dibandingkan dengan kontrol. Pada perlakuan 2 jam isolat dengan kode EB45 dan EB49 memiliki mortalitas tertinggi sebesar $25.54 \%$ dan $17.06 \%$, sedangkan pada perlakuan 6 jam isolat dengan kode EB13, dan EB45 merupakan isolat yang memiliki tingkat kematian nematoda parasit paling tinggi dengan jumlah $41.31 \%$ dan $39.55 \%$, dan pada perlakuan 12 jam isolat dengan kode EB13, EB28, EB45, EB48 dan EB49 merupakan isolat dengan jumlah nematoda yang mengalami mortalitas terbanyak dengan persentase berturut-turut $47.71 \%, 49.45 \%$, $53.74 \%, 51.41 \%$ dan $47.69 \%$.

Juvenil nematoda yang mengalami inaktif diduga terjadi karena adanya pengaruh senyawa metabolit yang dihasilkan oleh bakteri dan bersifat toksik terhadap nematoda parasit. Senyawa metabolit yang dihasilkan oleh bakteri endofit diantaranya yaitu pelarut fosfat dan enzim 
penghidrolisa seperti kitinase, protease, selulase, lipase, dan pektinase (Berg dan Hallmann 2006). Hartini (2004) melaporkan bahwa perlakuan kultur fitrat bakteri endofit yang diisolasi dari tanaman tomat mampu meningkatkan jumlah larva Meloidogyne spp. yang mengalami inaktif hingga $100 \%$. Selain itu, perlakuan filtrat isolat bakteri endofit yang diisolasi dari akar tanaman lada ada yang berpengaruh terhadap mortalitas larva nematoda hingga 86.3\% (Munif dan Harni 2011).

\section{KESIMPULAN}

Empat spesies Meloidogyne yang teridentifikasi berdasarkan karakter pola perineal yaitu $M$. incognita, $M$. arenaria, M. javanica, dan M. hapla. Sebanyak 11 isolat dengan kode isolat EA32, EA40, EB3, EB4, EB13, EB28, EB30, EB36, EB45, EB48, EB49 berhasil diisolasi dari tanaman kenikir yang digunakan untuk pengujian in vitro, 11 isolat ini merupakan isolat yang negatif uji hipersensitif dan uji aktivitas hemolisis. Isolat dengan kode EB13, EB28, EB45, EB48 dan EB49 merupakan isolat dengan jumlah mortalitas nematoda terbanyak dengan persentase berturutturut $47.71 \%, 49.45 \%, 53.74 \%, 51.41 \%$ dan $47.69 \%$ pada 12 jam setelah perlakuan.

\section{DAFTAR PUSTAKA}

Barker, K. R. \& Koenning, S. R (1998). Developing sustainable systems for nematode management. Annu Rev Phytopathol, 36, 165-205.

Berg, G. \& Hallmann, J. (2006). Control of plant pathogenic fungi with bacterial endophytes. Di dalam: Schulz BJE, Boyle CJC, Sieber TN, editor. Microbial Root Endophytes. Verlag Berlin Heidelberg (DE): Springer. hlm 53-66.

Caveness, F. E., \& Jensen, H. J. (1955). Modification of the centrifugal-flotation technique for the isolation and concentration of nematodes and their eggs from soil and plant tissue. Proc Helminthol Soc Wash, 25, 8789.

Das, P., Mukherjee, S., \& Sen, R. (2008). Antimicrobial potential of a lipopeptide biosurfactant derived from a marine Bacillus circulans. J Appl Microbiol, 104, 1675-1684.

Dropkin, V. H. (1991). Pengantar Nematologi Tumbuhan. Ed ke-2. Supratoyo, penerjemah. Yogyakarta (ID): Gajah Mada University Press. Terjemahan dari: Introduction to Plant Nematology.

Eisenback, J. D., Hirschman, H., Sassser, J. N., \& Triantaphyllou, A. C. (1981). A Guide to The Four Most common Species of Root-Knot Nematodes (Meloidogyne species) With a Pictorial Key. Washington DC (US): Cooperative Publication
Departement of Plant Pathology and U.S Agency International Development.

Goodey, T. (1973). Two methods for staining nematodes in plant tissue. J Helminthol.15: 137-144.

Hallmann, J., Hallmann, A.Q., Mahaffee, W. F., \& Kloepper, J. W. (1997). Bacterial endophytes in agricultural crops. Can J Microbiol, 43, 895-914.

Hartini, A. (2004). Isolasi bakteri endofit dan pengujian potensinya untuk mengendalikan nematoda Meloidogyne sp. pada tanaman tomat (Lycopersicon esculentum Mill.) [skripsi]. Bogor (ID): Fakultas Pertanian, Institut Pertanian Bogor.

Hertle, R., Hilger, M., Weingardt-Kocher, S., \& Walev, I. (1999). Cytotoxic action of Serratia marcescens hemolysin on human epithelial cells. Infection and Immunity, 67(2),817-825.

Hutagalung, L. (1988). Teknik Ekstraksi dan Membuat Preparat Nematoda Parasit Tumbuhan. Jakarta (ID): Rajawali Press.

Jawetz, E., Melnick, J. L., \& Adelberg, E.A. (1982). Microbiology for Medicine. 14th ed. Los Altos. California : Lange Medical Publications.

Jayasinghe, U. (2002). Potato seed in Indonesia: a baseline survey. Di dalam: Fuglie KO, editor. Progress in Potato and Sweetpotato research inIndonesia.Proccedings of the CIP-Indonesia Research Review Workshop. Bogor: International Potato Center.

Joklik, W. K., Willett, H. P., Amos, D. B., \& Wilfert, C. M. (1992). Zinsser Microbiology. 20th ed. California : Appleton and Lange.

Kasahara, S. \& Hemmi, S. (1995). Medicinal Herb Index in Indonesia, Ed ke-2. Jakarta (ID): Eisai Indonesia.

Kurniawati, F., Supramana, \& Adnan, M. A. (2017). Spesies Meloidogyne Penyebab Puru Akar pada Seledri di Pacet, Cianjur, Jawa Barat. Jurnal Fitopatologi Indonesia. 13(1), 26-30. DOI: 10.14692/jfi.13.1.2630 .

Lelliot, R. \& Stead, E. (1987). Methods for the Diagnosis of Bacterial Disease ofPlants. British: British Society for Plant Pathology by Blackwell Scientific Publ. Oxford london edinburgh

Luc, M., Sikora, R. A., \& Bridge, J. (2001). Nematoda Parasit Tumbuhan di Pertanian Subtropik dan Tropik. Ed ke-2. Supraptoyo, penerjemah. Yogyakarta (ID): Gadjah Mada University Press. Terjemahan dari: 
Plant Parasitic Nematodes in Subtropical and Tropical Agriculture.

May, W. F. \& Lyon, H. H. (1996). Pictorial key to Genera of Plant Parasitic Nematodes. Edisi ke-5. New York (US): Cornel University.

Melakeberhan, H., Wang, \& Wei. (2012). Suitability of celery cultivars to infection by populations of Meloidogyne hapla. J. Nematol, 14(5), 623-629.

Mulyadi. (2009). Nematologi Pertanian. Yogyakarta (ID): Jurusan Hama dan Penyakit Fakultas Pertanian Universitas Gadjah Mada.

Munif, A. \& Harni, R. (2011). Keefektifan bakteri endofit untuk mengendalikan nematoda parasit Meloidogyne incognita pada tanaman lada. Buletin Ristri, 2(3), 279-419.

Munif, A., Wiyono, S., \& Suwarno. (2012). Isolasi Bakteri endofit asal tanaman padi gogo dan potensinya sebagai agens biokontrol dan pemacu pertumbuhan tanaman. J Fitopatol Indones, 8(3), 57-64.

Park PW, Foster TJ, Nishi E, Duncan SJ, Klagsbrun M, and
Chen Y. (2004). Activation of Syndecan-1 ectodomain shedding by Staphylococcus aureus $\alpha$ toxin and $\beta$-toxin. J. Biol. Chem., 279(1), 251-258.

Prasasti, W. D. (2012). Strategi Pengendalian Penyakit Nematoda Puru Akar (Meloidogyne spp.) pada Tanaman Tomat (Solanun lycopersicum L.).yogyakarta (ID): UGM Press.

Rosya, A. \& Winarto. (2013). Keragaman Komunitas Fitonematoda pada Sayuran Lahan Monokultur dan Polikultur di Sumatera Barat. JFI. 9(3), 71-76. doi: 10.14692/jfi.9.3.7.1.

Whitehead, A. G. (1998). Plant Nematode Control. London: CAB International.

Yang He, S. (1996). Elicitation of plant hypersensitive response by bacteria. Plant Physiol. 112, 865-869.

Zhu, W., MaGbanua, M. M., \& White, F. F. (2000). Identification of two novelhrp-associated genes in the hrp gene cluster ofXanthomonas oryzae pv. oryzae. Journal of Bacteriology. 182(7):1844-1853. doi: 10.1128/JB.182.7.1844-1853.2000 